\title{
Implementation of Operations Management and Quality Management Company with Concrete Readymix Lean Sigma (Study in Readymix in East Java)
}

\author{
Teguh Herdijanto \\ Department of Economic Agustus University 17, Prof. Dr. Hj. Ratnawati, MS., Ak., CA. \\ Dr. Muslimin A. Rachim, M.SIE
}

\begin{abstract}
This study attempts to explain how Lean Sigma method implemented in a construction company Readymix in East Java. Data was obtained from a sample of five companies Readymixyang awarded for major industrial and financial resources derived from FDI (Foreign Direct Investment). There are two findings. First, the approach using Lean Sigma can be applied to the operation management based enterprise project Readyinix so it can be used as a reference to improve the performance of the organization and the second factor of the machine age and men to become the most dominant factor than other factors in the results of this study, where these factors are caused by not the machine age and the competence of human resources in the company.
\end{abstract}

Keyword: Operations Management. Quality Management, Lean Sigma, FMEA

\section{Introduction}

Growth of construction indicate the potential for developing an attraction of investors to invest in Indonesia. Government development plans which have been proposed in the current government, create great opportunities for entrepreneurs engaged in the construction of infrastructure in developing their business and projects included in the government's development plans. In addition to construction entrepreneurs, developments are also an opportunity for entrepreneurs Readymix to participate in infrastructure development in the provision of services Readymix concrete.

From some data that can be gathered in that the absence of a service company Readymix applying Lean Sigma method, it can be seen from several institutions management consultant seen from the list of clients for Lean Sigma have not found any construction company based Readymix. That is because the notion that Lean Sigma can only be run on large companies and manufacturing companies only. Many people assume that the only suitable method of Lean Manufacturing applied in the company great. Indeed, there is much evidence to support that idea, the majority of companies which is famous for its Lean is a multi-millionaire like Toyota, Danaher, Ford, Amazon, General Electric, and several other companies are a bit smaller than some of the giants mentioned above.

Similarly, Lean Manufacturing, Six Sigma although that is part of the Lean Sigmayang first developed by manufacturers like Motorola and GE. But now many companies both services, mining, even governments apply the principles of Six Sigma improvement, namely Bank Mandiri, which was once a Best Six Sigma Project Award in Six Sigma Conference in 2009 and PT. PLN electricity power distribution company owned by the government. There are so many benefits that the two organizations on the implementation of Six Sigma.

The rationale of this study was to identify whether the approach using Lean Sigma method can be applied to the management of project-based operating companies Readymix so it can be used as reference for improving organizational performance. It is expected that a different strategy would require different management techniques to remain competitive in the business world of its kind. It is expected that with this study may open discourse and can be used Itier' ature as a reference for the implementation of the strategy in the operational management of the company Readytnix in East Java.

\subsection{Operations Management}

\section{Theory Study}

In carrying out the production of a company, we need a useful management to implement decisions in an effort to organizing and coordinating the use of resources from production activities are known as production management or operational management. According to Jay Heizer and Barry Render $(2014 ; 4)$ Operations management is a series of activities that produce value in the form of goods and services by transforming inputs into output.Sedangkan by Eddy Herjanto (2009: 2) operations and production management can be defined as a process that is sustainable and effective use of management functions to integrate various resources efficiently in order to achieve the goal ". 
From the definition that has been presented, we can conclude that the management of production and operation of a set of processes to create goods or services or activities which change shape to create or add to the benefits of a good or service that will be used to meet human needs.

\subsection{Quality Management}

Quality management has a meaning as an act of overseeing all the activities and tasks needed to maintain the desired level of excellence. This includes the determination of the quality policy, creating and implementing a quality planning and assurance, and quality control and quality improvement.

Conceptually, quality management can be applied both in barangmaupun services, because the emphasis in the implementation of quality management system kualhasadalah improvement. Basically, the process industry must be viewed as a continuous improvement (continuous industrial process improvement), which starts from sederetsiklus since their ideas to produce a product, pengembanganproduk, the production process, to distribution to the consumer. So on the basis of information as feedback collected from users of the product (customer) it can develop creative ideas to create new or improve products and their long product production processes that exist today.

\subsection{Lean Sigma}

Lean can be defined a systemic approach and systematic to identify and eliminate waste or activity activity is not value-added (non value adding activities) through peniingkatan continuously radically by flowing the product and information system using tensile (pull system) of internal and external customers to the pursuit of excellence and perfection. Six Sigma can be defined as a methodology that provides the tools a tool to improve business processes with the aim of reducing process variation and improve product quality. Six sigma approach is a set of concepts and practices that focuses on reducing process variation and a decrease in failures or defects of products that includes phases Define, Measure, Analyze, Improve and Control. Important elements in six sigma is to produce only 3.4 defects per one million opportunities or surgery (3.4 DPMO)), the initiative process improvement initiatives to achieve six sigma levels of performance.

Lean Six Sigma is a combination of lean and Six Sigma can be defined as a business philosophy, a systemic approach and systematic to identify and eliminate waste (waste) or activity activity value-added (nonvalue added activities) through continuous improvement of the radical to achieve six sigma performance levels, by flowing the product and information system using pull (pull system) of internal and external customers for the pursuit of excellence and perfection of form only produce 3.4 defects per one million opportunities or operations 3.4 DPMO (defects per million Opportunities).

\subsection{Research procedures}

\section{Methodology}

Based on the characteristics of the problem of this research can be classified as exploratory research with the characteristics of the problem of implementation of Lean Sigma method in the process of Readymix. The incorporation of Lean and Lean Six Sigma is required because can not usher process under statistical control while Six Sigma alone can not dramatically increase the speed of the process. The merger between Lean and Six Sigma methods can be served on the image below:

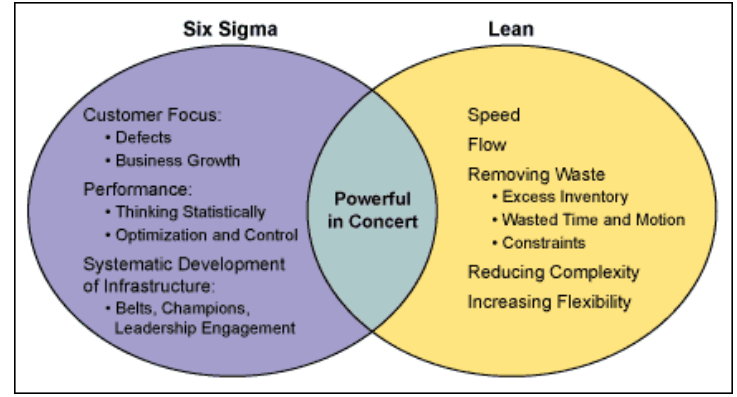

Figure 3.1 Relationship between Lean and Six Sigma methods

Equipment / data collection instruments used in this study is the data plan and the realization of the project as well as data and types complaian complain that often occurs for the period July to December 2015.

\subsection{Characteristics of Sample}

The study population was Readymix industrial companies in the province of East Java. Target sample in this study is planned chosen from several companies Readymix with a category as large industrial course, this is because both of these categories is a company that has a working system intact as a factory Readymix in the

DOI: 10.9790/487X-1907024247 $\quad$ www.iosrjournals.org $\quad 43$ |Page


sense that the company has a range of complete working either as factory so material as well as factories that produce raw materials. Meanwhile, from the aspect of capital invested in the company, the selection of the target population is aimed at companies that most of its financial resources come from the FDI (Foreign Direct Investment), this will obviously help facilitate researchers gain criterion or measure which would have been good about the system process and the size of the employee perfoirnance, considering all companies with a financial basis, has had standardization in all aspects of company operations, including about system processes and performance measurement of employees required in this study.

\subsection{Define}

\section{Analysis Of Results}

This stage is the initial step in the framework of Lean sigma quality improvement program. Some things need to be done in this regard, the choice of objects and determination Lean sigma objectives to be achieved. Then in doing the identification of QTC-forming characteristics of the products researched and defined the key processes in Lean Sigma project along with its customers. Based on the brainstorming done by the management company in charge some particular quality characteristics found in Readymix process. The Readymix process quality characteristics are shown in the following table:

Table 4.1 Characteristics (QTC) of the Readymix concrete

\begin{tabular}{|c|l|l|}
\hline \multirow{4}{*}{$\begin{array}{c}\text { Process } \\
\text { Readymix } \\
\text { Concrete }\end{array}$} & Characteristics QTC & Criteria Defect \\
\cline { 2 - 3 } & delivery of products & concrete delivery late \\
\cline { 2 - 3 } & volume product & less volume of demand \\
\cline { 2 - 3 } & specifications slump & Slump is not within specifications \\
\cline { 2 - 3 } & compressive strength & compressive strength is not within specifications \\
\hline
\end{tabular}

Source: Secondary data is processed, 2016

\subsection{Measure}

This stage is the second operational step in Lean sigma quality improvement program. At this stage pengembangkan a plan based on the collection of data through pengkuran that can be done at the process level and measure the current performance baseline (Current performance) at the process level to be applied as a baseline performance (performance baseline). The measurements determined using PerOpportunities Defect measurement unit (DPO), Defect Per Million Opportunities (DPMO) and the level of capability Sigma.

The results of calculation DPO, DPMO and sigma values can be seen in the following table:

Tabel 4.2 Nilai DPO, DPMO dan nilai sigma

\begin{tabular}{|c|c|c|c|c|c|c|c|}
\hline $\begin{array}{c}\text { Object } \\
\text { Research }\end{array}$ & Month & $\begin{array}{c}\text { Total } \\
\text { Project }\end{array}$ & $\begin{array}{c}\text { Total } \\
\text { Defect }\end{array}$ & $\begin{array}{l}\text { Total } \\
\text { QTC }\end{array}$ & DPO & DPMO & $\begin{array}{l}\text { Sigma } \\
\text { Value }\end{array}$ \\
\hline \multirow{6}{*}{$\begin{array}{l}\text { PT. Varia } \\
\text { Usaha Beton }\end{array}$} & July & 538 & 23 & 4 & $\overline{0.0107}$ & $10,687.73$ & 3.80 \\
\hline & \begin{tabular}{|l|} 
August \\
\end{tabular} & 725 & 27 & 4 & $\overline{0.0093}$ & $9,310-34$ & 3.85 \\
\hline & September & 744 & 26 & 4 & 0.0087 & $8,736.56$ & 3.87 \\
\hline & October & 810 & 25 & 4 & 0.0077 & $7,716.05$ & 3.92 \\
\hline & November & 775 & 26 & 4 & $\overline{0.0084}$ & $8,387.10$ & 3.89 \\
\hline & December & 690 & 27 & 4 & 0.0098 & 9,78261 & 3.84 \\
\hline \multirow{6}{*}{$\begin{array}{c}\text { PT. Jaya } \\
\text { Readymix }\end{array}$} & July & 538 & 26 & 4 & 0.0121 & $12,081.78$ & 3.76 \\
\hline & August & 667 & 25 & 4 & 0.0094 & $9,370.31$ & 3.79 \\
\hline & September & 806 & 27 & 4 & $\overline{0.0084}$ & $8,374.69$ & 3.80 \\
\hline & October & 690 & 26 & 4 & 0.0094 & $9,420.29$ & 3.82 \\
\hline & November & 775 & 25 & 4 & 0.0081 & $8,064.52$ & 3.80 \\
\hline & December & 780 & 26 & 4 & $\overline{0.0083}$ & $8,333.33$ & 3.80 \\
\hline \multirow{6}{*}{$\begin{array}{l}\text { PT. Pionir } \\
\text { Beton }\end{array}$} & July & 651 & 27 & 4 & $\overline{0.0104}$ & 10,368666 & 3.76 \\
\hline & \begin{tabular}{|l|} 
August \\
\end{tabular} & 696 & 28 & 4 & $\overline{0.0101}$ & $10,057,47$ & 3.79 \\
\hline & September & 775 & 26 & 4 & 0.0084 & $8,387.10$ & 3.80 \\
\hline & October & 690 & 24 & 4 & 0.0087 & $8,695.65$ & 3.82 \\
\hline & November & 806 & 25 & 4 & 0.0078 & 7,754 .34 & 3.80 \\
\hline & December & 720 & 24 & 4 & 0.0083 & $8,333.33$ & 3.81 \\
\hline \multirow{6}{*}{$\begin{array}{l}\text { PT. Holcim } \\
\text { P1ant Surabaya }\end{array}$} & July & 538 & 27 & 4 & 0.0125 & $12,546.47$ & 3.77 \\
\hline & \begin{tabular}{|l} 
August \\
\end{tabular} & 725 & 28 & 4 & 0.0097 & $9,655.17$ & 3.79 \\
\hline & September & 682 & 26 & 4 & $\overline{0.0095}$ & $9,530.79$ & 3.80 \\
\hline & October & 630 & 27 & 4 & $\overline{0.0107}$ & 10,71429 & 3.82 \\
\hline & November & 713 & 28 & 4 & 0.0098 & $9,817.67$ & 3.80 \\
\hline & December & 690 & 25 & 4 & 0.0091 & $9,057 \_97$ & 3.80 \\
\hline \multirow{6}{*}{$\begin{array}{l}\text { PT. Duta } \\
\text { Bangsa } \\
\text { Mandiri }\end{array}$} & July & 538 & 23 & 4 & 0.0107 & $10,687,73$ & 3.76 \\
\hline & \begin{tabular}{|l|} 
August \\
\end{tabular} & 609 & 25 & 4 & 0.0103 & $10,262.73$ & 3.79 \\
\hline & September & 744 & 26 & 4 & 0.0087 & $8,736.56$ & 3.88 \\
\hline & October & 780 & 25 & 4 & 0.0080 & $8,012.82$ & 3.91 \\
\hline & November & 713 & 28 & 4 & 0.0098 & $9,817 \_67$ & 3.84 \\
\hline & December & 750 & 25 & 4 & $\overline{0.0083}$ & $8,333.33$ & 3.89 \\
\hline
\end{tabular}

Source: Secondary data is processed, 2016

\subsection{Analyze}

At this stage in doing some steps to analyze the results of measurements that have been done in the previous stage. The step is to determine the ability / capability (capability) '-of the Readymix, and the identification of the sources of the root causes of non-compliance processes generated. 
Based on the calculation method ToKind Pareto mismatch process, which ranks first concrete Delivery late (225 times or $28.99 \%$ ), the second position is strong-press is not within specifications (201 times or $25.90 \%$ ), the third position is slump does not according to specifications (200 times or 25.77\%) and the last position volume is less than demand (150 times or $19.33 \%$ ).

Furthermore, the main root of a problem can be analyzed using cause and effect diagram which would lay a detailed breakdown because it causes a problem. From the results of which will serve as an indicator to predict whether the most dominant factors that cause customer complaint with Partial Least Square test. Based on these test results, factors used machinery and human labor is the dominant factor in influencing the number of customer complaint. Where the engine factor caused by the machine age that is long enough, the labor factor caused by the competence of the employees who are still lacking. Based on the structural model that has been qualified, it can be presented frame models and each coefficient of causality in the following figure:

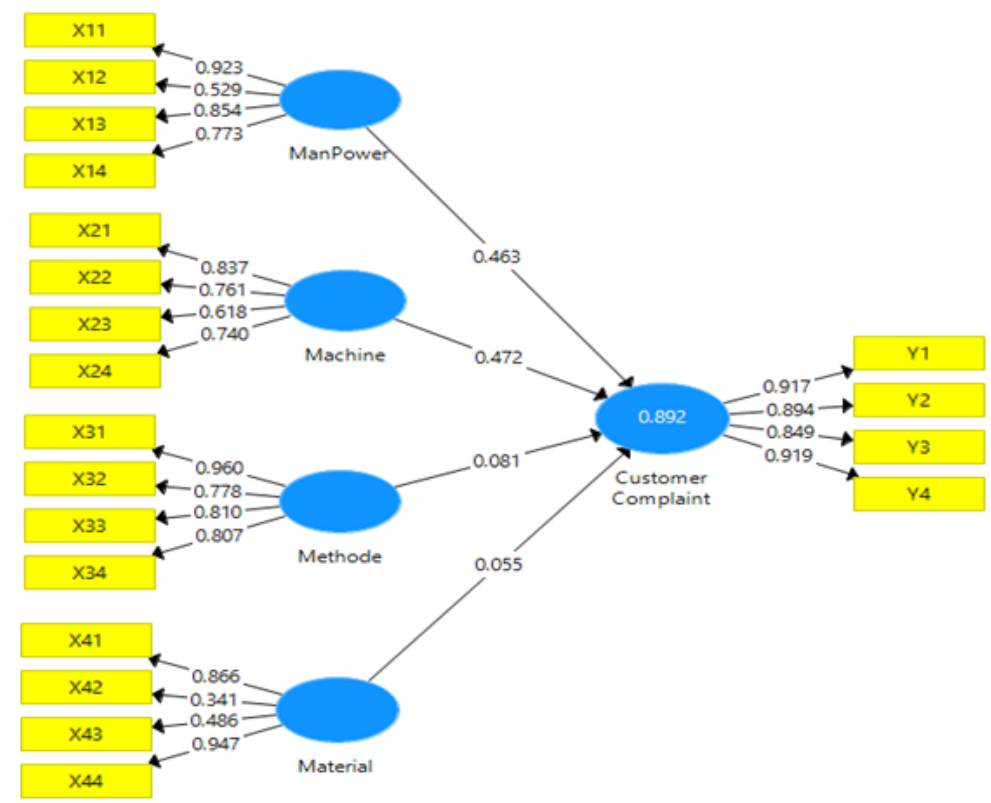

Figure 4.1Hasil test Partial Least Square

Source: Output SmartPLS

\subsection{Improve}

At the stage of improvement (improve) is to create a corrective action plan and improvement (action plan) to eliminate the root causes and prevent the root causes of the problem in order to avoid returning to the production process to come Of alternatives - alternatives exist, then the ranking that can be prioritized corrective actions to be performed based on the cause of the failure. Ranking obtained using FMEA based on the value that exists is a hassle (severity), the 'probability of occurrence (occurance) and detekbilitas (detecbility) together - together then obtained value RPN (Risk Priority Number) which is obtained by multiplying severity, occurance and detecbility, By focusing on the problem - a potential problem that has the highest priority, where the largest RPN value, then it can be taken - action to reduce the risk of failure.

Based on the results of a calculation FMEA, the proposal perbaikanya action priorities can be seen in the following table:

Table 4.3. FMEA table for priority repairs

\begin{tabular}{|c|c|l|}
\hline $\begin{array}{c}\text { To- } \\
\text { Priority }\end{array}$ & $\begin{array}{c}\text { Risk Priority } \\
\text { Number }\end{array}$ & \multicolumn{1}{c|}{ Proposed remedial actions } \\
\hline 1 & 320 & Providing training to employees to improve work \\
\hline 2 & 256 & Placing employees according to specializations \\
\hline 3 & 256 & Gives a warning to employees to not make mistakes in control \\
\hline 4 & 256 & Make a procedure at work (SOP) \\
\hline 5 & 256 & Briefed by supevisor on employees \\
\hline 6 & 256 & Improve the way employees work in the mixing process to be more careful - careful \\
\hline 7 & 256 & Strictly checking every material coming \\
\hline 8 & 252 & Checking the material composition in accordance with standard \\
\hline 9 & 224 & Level control to be checked before each production process \\
\hline 10 & 90 & Perform maintenance and cleaning of the mixer preventively \\
\hline
\end{tabular}




\subsection{Control}

Control is the last operational phase of the project implentasi Lean Sigma. In this phase created a mechanism control system either process it for controlling the standard specification as well as to control the operating instruction so that every process and subprocess can be controlled so that a discrepancy of products and processes that take place will not be repeated again and failure conditions of zero (zero defect) that is the target of the operational management implementation with Lean Sigma approach. The most common tool used is a control diagram. General function control diagram is to help reduce the variability, monitor performance at all times, enabling the correction process to prevent rejection and order trends and conditions beyond its control accurately detected.

\section{Discussion}

From the results of a calculation DPO and DPMO level mismatches that resulted in the complaints process from July to December 2015 at 3.82 to the value of Sigma. Critical quality of elected, delivery delay factor into the most dominant factor than other factors. Where the delay in delivery is accounted for as much as $28.99 \%$ of the total complaints, where these factors are out of sync due to its inter-ministerial communication terkait.Faktor competence of the existing human resources also need to be improved as well as the culture of the organization also need to be considered in order to improve the quality of operational management Readymix construction services.

Experience in the US shows that when companies implement and focus all resources on the concept of Six Sigma, he will obtain the following results:

a. An incrase in 1-sigma of 3-to 4-Sigma Sigma in the first year.

b. In the second year, the increase will take place from 4 to 4.7-Sigma-Sigma.

c. In the third year, the increase will take place on the 4.7-to 5-Sigma Sigma.

d. In the fourth year, the increase will take place from 5-to 5.1-Sigma Sigma.

e. In subsequent years, the average increase was 0.1-Sigma-Sigma to a maximum of 0.15 per year.

World-class companies are very concerned about the quality yaag takes an average of 10 years to switch from 3-sigma operational level (66,810 DPMO-failures per million opportunities) became operational level 6-Sigma (3,4DPMO failures per million opportunities), which means having an increase of about $66810 / 3.4=19650$ times over 10 years, or on average about 1965 "improvement" every year. A dramatic increase. Improvement of 3-4.7-Sigma Sigma to deliver results follow an exponential curve, while an increase of 4.7-to 6-Sigma Sigma follows a linear curve.

\section{Conclusion}

Based on the research that has been done on kontruksiReadymix services company in East Java on how the implementation of Lean Sigma in the operational management of the company, to some conclusions as follows:

a. The approach using Lean Sigma can be applied to the operation management based enterprise project Readymix so it can be used as a reference to improve the performance of the organization, it is supported by the experience in the United States shows that when companies implement and focus all resources on the concept of Six Sigma, he will gain consistent improvement towards a level of 6 Sigma.

b. Factors delivery delay becomes the dominant factor than other factors in the results of this study, where these factors are out of sync due to its inter-ministerial this communication .Age Factor machine and competence factor of the existing human resources also need to be increased as well as the culture of the organization is also worth noting in order to improve the quality of the operational management of the construction services Readymix.

\section{Weaknesses And Suggestions}

Because this study tries to examine how the implementation of the methods of Lean Sigma management operational at the construction company Readymix, then because the research was only done in the scope of the area of East Java, which means a limited scope, and therefore the results of this study can not be generalized in general in the region broader or in other regions From the discussion and conclusions of research, it can be argued Keys to the success LeanSigma project is consistent with the corrective action. The advice given researchers are continuously improving operational quality by focusing on the customer so that it can achieve its vision undergo a competitive rivalry. One attempt to improve operational quality that focuses on the customer is to do the design improvements that have been compiled in this study.

\section{References}

[1]. Ahyari, Agtis. 2010, Production Management and Production System Planning, 4th Edition, BPFE, Yogyakarta

[2]. Arikunto, Suharsimi. 2010. Procedure Research: A Practical Approach. Revised edition, 2010. Jakarta: Rineka Reserved.

[3]. Assauri, Sofyan, 2011, Production and Operations Management, Revised Edition, Publisher Institute of the University of Indonesia, Jakarta 
Implementation of Operations Management and Quality Management Company with Concrete ..

[4]. Chase, Richard B., Nicholas J. Aquilano, F. Robert Jacobs, 2001, Operations Management for Competitive Advantage, 9thEdition, Mc Graw-Hill

[5]. Cohran, W.G. 2005. Mechanical Withdrawal Sampel.Terj. Rudiansyah. Ed. 3. Jakarta: UI. Press

[6]. E.Wood Buffa. 2009. Production and Operations Management. The sixth edition of the second volume. Erland. Jakarta

[7]. Evans, Lindsay. (2005). The Management and Control of Quality, Sixth Edition, South-Western THOMSON, Singapore.

[8]. Evans, Lindsay. (2007). Introduction to Six Sigma: An Introduction to Six Sigma and Process Improvement, Salemba Four, Jakarta.

[9]. Fitzsimmons, James A Fitzsimmons, Mona J. (2006). Service Management: Operations, Strategy, Information Technology. McGraw-Hill, USA.

[10]. Gaspersz Vincent. 2007, Lean Six Sigma for Manufacturing and Service Industries, Gramedia Pustaka Utama

[11]. Gaspersz Vincent. 2008, The Execeutive Guide To Implementing Lean Six Sigma, Gramedia Pustaka Utama

[12]. George, Michael L. (2005). The Lean Six Sigma Pocket Toolbook: A Quick Reference Guide To Nearly 100 Tools For Improving Process Quality, Speed, And Complexity. McGraw-Hill, USA.

[13]. George, Michael L. (2005). Lean Six Sigma For Service: How To Use Speed Lean And Six Sigma Quality To Improve Services And Transactions. McGraw-Hill, USA.

[14]. Glaser, Barney G \& Strauss, Anselm L., (1967). The Discovery of Grounded Theory: Strategies for Qualitative Research, Chicago, Aldine Publishing Company

[15]. Hair, et al. (2006). Multivariate Data Analysis. Sixth Edition. New Jersey: Pearson Education

[16]. Heizer, Render. (2009). Operations Management, vol-1, Salemba Four, Jakarta.

[17]. Hendradi C. Tri. (2007). Six Sigma Statistics with Minitab: The Smart Guide 6 Sigma Quality Initiative, Publisher ANDI, Yogyakarta.

[18]. Hidayat, Sam. 2009. Six Sigma strategy. PT Elex Media Komputindo. Jakarta

[19]. Krawjesky, L.J \& Ritzman, L.P 2011. Operations Management: Strategy and Analysis. Sixth Edition. Prentice-Hall International, Inc.

[20]. Kuncoro, M. (2009). Research Methods for Business and Economics. 3rd edition Jakarta: Erland

[21]. Latif and Utami. (2009). Application of Six Sigma Approach Methods in the Care Quality in Construction Projects, Department of Civil Engineering, Faculty of Engineering, University of Indonesia, 16424, Indonesia, Depok.

[22]. Limanto, S., Arief, TA, Josep, B., Sanjaya, A. 2002 Preliminary Studies Readymix Concrete Company Policy by Using Fuzzy Methods In Choosing supplying Concrete Materials, Surabaya, Indonesia: Final Civil Engineering, Kristen Petra University, Surabaya.

[23]. Limanto, S., Ehandra, L.P., Sutanto, A., Gunawan, T., 2006, Operational Risk Management Division Readymix Concrete, Surabaya, Indonesia: Final Civil Engineering, Kristen Petra University, Surabaya.

[24]. Miranda and Single. (2006). Six Sigma (a general overview, the application process, and methods used to repair GE and MOTOROLA), Harvarindo, Jakarta.

[25]. Neuman, W, L. (2006). Social Research Methods: Qualitative and Quantitative Approaches. Sixth Edition, Pearson International, Inc.

[26]. Pande, Neuman, Cavanagh. (2003). The Six Sigma Way, Publisher ANDI, Yogyakarta.

[27]. Pande, Neumann, Roland R.Eavanagh.2002. The Six Sigma Way How GE, Motorola and Other Brands Company Sharpen Those performance. ANDI. Yogjakarta

[28]. Pande, Pete and Larry Holpp. (2005). What is Six Sigma (Quick Thinking Six Sigma), Publisher Andi, Yogyakarta.

[29]. Pete \& Holpp.2002. What Is Six Sigma. ANDI. Yogjakarta.

[30]. Riduwan and Sunarto,2007. Statistics for the study. Bandung: Alfabeta.

[31]. Sandjojo, Nidjo.2011. Path Analysis Method and Its Application. Jakarta: Pustaka Sinar Harapan

[32]. Sarwono, Jonathan. 2015. Make Theses and Dissertations by Partial Least Square SEM. Yogyakarta: Andi

[33]. Siagian, Faira and Sekarsari, Jane. 2001 Application of Risk Management Model in Construction Project Joint Venture in Indonesia A Case Study. Trisakti University, Jakarta.

[34]. Singgih S. (2007). Total Quality Management (TQM) and Six Sigma, Elex Media Komputindo, Jakarta.

[35]. Spradley, James. P. (1979). The Ethnographic Interview. New York: Holt, Rinehart and Winston

[36]. Sugiyono. (2009). Business Research Methods. CV. Alfabeta, Bandung. Thomas Pyzdek. 2002, Six Sigma Handbook, Publisher Salemba

[37]. Widarjono, Agus. 2007. Econometric Theory and Applications to Economics and Business. Ekonisia. Yogyakarta

[38]. Yamit, Zulian. (2004). Management Quality Products and Services, Ekonisia, Yogyakarta.

[39]. $\mathrm{Zu}$ and Fredendall. (2009). Six Sigma Implementation Through Enhancing Human Resource Management, The Quality Management Journal.

Teguh Herdijanto. "Implementation of Operations Management and Quality Management Company with Concrete Readymix Lean Sigma (Study in Readymix in East Java)." IOSR Journal of Business and Management (IOSR-JBM) 19.7 (2017): 42-47. 